\title{
Land inequality, government ideology and agricultural protection
}

\author{
Alessandro Olper * \\ Dipartimento di Economia e Politica Agraria, Agroalimentare e Ambientale - Università degli Studi di Milano, \\ via Celoria 2, 20133 Milano, Italy
}

Accepted 16 March 2006

\begin{abstract}
This paper presents an empirical investigation of how agricultural land ownership inequality and government ideology (right-wing vs. left-wing) affect agricultural protection. Theoretically, the links are quite ambiguous, switching from positive to negative depending on the structure of the underlying political economic model - i.e. pressure groups vs. median voter approach. The data show, overall, that protection is decreasing in land inequality and with left-wing government orientation, but not in a linear fashion: left-wing governments tend to support agriculture in more unequal societies. There is some evidence that the relationship holds better in democracies than in dictatorships.

(c) 2006 Elsevier Ltd. All rights reserved.
\end{abstract}

Keywords: Land inequality; Ideology; Political economy; Agricultural protection

\section{Introduction}

In the last decade problems of land inequality have attracted renewed interest in the development literature due to the notion that inequality is economically costly (Deininger and Olinto, 2000; Timmer, 2002) and due to new political pressure for land reform in countries with unequal land distribution (Swinnen, 2002). However, few attempts have

\footnotetext{
${ }^{*}$ Tel.: +39 02 70600455; fax: +3902 70638437.

E-mail address: alessandro.olper@unimi.it.
} 
been made to analyze the link between land inequality and agricultural protection patterns (see De Gorter and Swinnen, 2002 for a recent survey). More in general, the implication of the distribution of assets ownership for trade protection is a much neglected aspect of the current political economic literature (Mitra, 1999).

There could be two main reasons for this neglect. First, the role of inequality has often been obfuscated in political economic studies because it was confused with that of group size. Indeed, the tendency is to consider small groups as being effective, largely because their are homogeneous (Baland and Platteau, 1997).

The second reason is that the most political economic models of agricultural policy formation consider interest groups to be exogenous, so that any analysis leaves out the effect of within-group heterogeneity (Barrett, 1999). ${ }^{1}$ However, it has been suggested that assets inequality could have a substantial effect on both collective action and government redistribution, thus affecting the provision of public goods (see Stiglitz, 1998; Bardhan et al., 2001) and the social demand of the median voter (see Mayer, 1984; Alesina and Rodrik, 1994). This seems especially true at the agricultural level, where owning land gives different externality at both the economic (i.e. access to credit, risk propensity) and the socio-political level (i.e. social status, political power).

Starting from these considerations, the aim of the paper has been to empirically investigate the relationship between land distribution inequality and patterns of agricultural protection, taking into consideration also the potential role played by the ideological orientation of the government. Indeed, in an unequal society, left-wing government may have a strong rationale for redistribution and thus potentially affect the interplay between inequality and protection. The data strongly support these predictions. Specifically, controlling for development, comparative advantage, agricultural sector size, and political institutions, it will be shown that protection is decreasing in land inequality and with left-wing government orientation, but not in a linear fashion: left-wing governments tend to support agriculture in more unequal economies.

The main contribution of the paper is to add to the empirical literature on cross-country variation in agricultural protection. Specifically, the results uncover a robust empirical regularity in the relationship between agricultural protection, land inequality and government ideology. That these relationships are not without interest is documented by recent papers that have started studying, both theoretically and empirically, the interplay between these dimensions in the context of endogenous trade policy.

The first message from this literature is the suggestion that the interplay between inequality and protection is often ambiguous (see Pecorino, 1998; Magee, 2002) and is strongly linked to the assumption of the underlying political economic model (see Dutt and Mitra, 2002). A second message suggests that because trade policy depends not only on the extent to which the government wants to redistribute income, but also on the country's overall factor endowments and their redistribution, both the partisan nature of the government - i.e. whether it is pro-rural or pro-capital - and assets inequality, could affect trade policy determination (Dutt and Mitra, 2003). The paper gives a preliminary assessment of this prediction in the context of agricultural trade policy.

\footnotetext{
${ }^{1}$ Exceptions to this rule can be found in De Janvry et al. (1989), Binswanger and Deininger (1997) and Barrett (1999).
} 
The remainder of the paper is organized as follows. Theory and previous evidences section briefly analyses how the literature accounts for the link between assets inequality, government ideology and protection, with special emphasis being given to agricultural policy. Data and basic specification section describes the data and basic specification. Econometric methodology and results section presents the empirical strategy and the results. At the end there is a brief discussion of the results and some concluding comments.

\section{Theory and previous evidences}

A brief account of the theoretical and the empirical literature on the link between assets inequality, government orientation and trade protection is given. The focus is on two main strands of the literature, namely the literature on endogenous trade policies and that on assets inequality and collective action.

\section{Inequality and endogenous protection}

In recent political economic models, the relationship between assets inequality and income distribution has often been based on the Downsian, median voter, framework (see Alesina and Rodrik, 1994). Within this framework the degree of inequality tends to have a positive influence on the degree of redistribution, regardless of who governs. ${ }^{2}$

However, the median-voter approach within a Heckshcer-Ohlin framework predicts that any increase in assets inequality, holding constant the economy's overall relative endowments, raises trade barriers in capital-rich countries and lowers them in labor-abundant economies (Mayer, 1984). Dutt and Mitra (2002) found considerable empirical support for this prediction in a large cross-section of countries.

One key feature of the above result is the recognition that governments, in setting trade policies, give considerable weight to general-interest rather than to special-interest groups. ${ }^{3}$ However, the applicability of this reasoning to agricultural protection is not so straightforward. In fact, agricultural policy, especially in the developed world, is probably one of the clearer examples of special-interest politics, where policy decisions create concentrated benefits for a few well-defined groups. Moreover, analyzing the effect of land inequality within a Heckscher-Ohlin framework is not very meaningful.

However, if we depart from the median voter approach and go to the prediction of lobbying models, we do not find clear predictions on the link between assets inequality and trade protection.

For example, Pecorino (1998) focuses on lobby formation, and tariffs are assumed to be an increasing function of campaign contributions. In this setting he shows that there is no presumption that an increase in concentration overcomes the free-rider problems, and this can lead to ambiguity in the link between industry concentration and tariffs. On the other hand, Mitra (1999) assumes that an interest group forms only if the generated rents are

\footnotetext{
${ }^{2}$ However, this prediction is quite inconsistent with the data (see, Deininger and Squire, 1998, and the papers cited therein).

${ }^{3}$ Similar conclusions were found by Goldberg and Maggi (1999) and Gawande and Bandyopadhyay (2000) in testing the Grossman and Helpman (1994) model on the US protection structure.
} 
sufficient to cover the fixed costs of lobby formation. The author shows that a greater degree of inequality in assets distribution may result in the formation of a larger number of lobbies, suggesting a positive link between inequality and tariffs. Finally, Magee (2002) extends the work of Pecorino (1998) and shows that the relationship between concentration, free riding and trade protection changes under different parameter conditions, leading to linearly increasing or decreasing relationships, or even non-monotonic ones, between concentration, free riding and tariffs.

The literature on lobby activities and tariff formation is related to the more general problem of the collective action and public goods provision. Thus, to gain new insight, and avoid the ambiguity of the above results, let us look at the recent literature on assets inequality and collective action.

\section{Inequality and collective action}

Is group participation higher or lower in more unequal communities? The literature addresses this question in different and contrasting ways. Starting from the seminal contributions of Olson (1965), and Bergstrom et al. (1986) who, respectively, predicted a positive and a neutral effect of income inequality on public goods provision, the recent literature has stressed the possibility of a negative impact of increased inequality on the collective action (see Baland and Platteau, 1997 for a survey).

The traditional argument of Olson is that if inequality leads to the emergence of one dominant player, then such dominance could alleviate collective action problems through the internalisation of the externalities. ${ }^{4}$ However, Baland and Platteau (1997) stressed that when assessing the impact of inequality on the success of collective action, two contrasting effects are at work. On the one hand, there is Olson's argument discussed above, while on the other hand, it has been shown that increased inequality can lead to less collective action when free-rider problems get worse for the poor and the set of contributors shrinks substantially. Thus, the net effect of inequality on collective action depends crucially on the relative strengths of these two contrasting effects. The same authors stress that this 'neutrality result' holds true only under quite restrictive conditions, reducing its relevance in many realistic applications.

Bardhan et al. (2001) depart from these limitations, showing that when there are market imperfections in input that are complementary to the collective goods, the relationship between increased inequality and collective action (and efficiency) will be negative for public goods and inverse U-shaped for common property resources (CPR).

This negative link hypothesis is supported by limited, but growing, empirical literature on assets (land) inequality and collective action. For example, studies based on micro-level survey data have reported a close negative association between farmers' inequality in land ownership and their ability to resolve collective action problems, such as the forming of water management organizations (Easter and Palanisami, 1986), co-operating in water allocation (Bardhan, 2000; Bardhan and Dayton-Johnson, 2002), and participating in groups like co-operatives, rotating savings and credit associations (La Ferrara, 2002). Thus, if an individual's incentive to join a group is affected by heterogeneity in assets

\footnotetext{
${ }^{4}$ Van Bastelaer (1998) found some support for this positive effect of land inequality on agricultural protection, by using the number of holdings per agricultural worker, as proxy for land distribution.
} 
ownership, the problems of collective action could suggest a negative link between land inequality and agricultural protection.

In the context of agricultural policy formation, two recent papers considered interest groups to be endogenous. Indeed, Barrett (1999) analyzes the economic incentives of coalitions for food price policy, recognizing the heterogeneity of interests across households. He shows that, other things being constant, household land holdings per capita is a factor affecting both the formation of groups and their alignment on food price policy. Thus, because unequal land distribution reinforces the number of net farm buyers who act in favor of low price policies, his model predicts a negative link between land inequality and protection.

More generally, Binswanger and Deininger (1997) highlighted three main channels through which land inequality could affect agricultural policy. First of all, land inequality reduces the participation of the poor in the political process, both directly and indirectly. This, in turn, reduces the likelihood of the poor having access to education and health care services, reinforcing their collective action problems. Finally, inequality might hinder the establishment of independent and impartial institutions, and the enforcement of binding rules.

Casual observation seems to fit in quite well with this negative link hypothesis. For example, agricultural price protection in East and Southeast Asia emerged only after strong land reform (Binswanger and Deininger, 1997). By contrast, in many African countries and, especially, in Latin America, strong inequality in land distribution has often been associated with direct and indirect agricultural policy taxation (see Krueger et al., 1991).

\section{Government ideology and trade policy}

Till now we have left out the possibility that the response of redistributive trade policy to land inequality differs, depending on the kind of government in power. However, if politicians are 'partisan' - left-wing and right-wing governments have different objective functions - then the interplay between land inequality and protection could also be related to the ideological orientation of the government.

In fact, the Stolper-Samuelson theorem tends to suggest that trade politics could be class politics because political parties tend to be affiliated with particular economic classes. If this is the case, then trade policy may become an issue for the partisan competition. For instance, in America in the 19th century, the Democrats supported by farmers pushed for free trade, while the Republicans aligned with manufacturers and workers advocated protection (see Hiscox, 2002).

The literature gives several definitions and interpretations of the term ideology. For example, a view is that it stands for the self-defined notions of public interest and altruistic goals of political parties, which form the basis for most economic policy making (Kau and Rubin, 1979). Differently, other authors suggest that the interests of constituents and ideological preferences of politicians are interrelated, with the former probably determining the later (Peltzman, 1984).

Our objective is to analyze whether agricultural policy is affected by the ideological orientation of the government, and this is independent of which kind of ideology definition one adopted. Thus, following the classical treatment in political economic models, we simply assumes that politicians care about the well being of particular groups in society, irrespective of the (true) underlying reasons. For example, left-wing governments 
may adopt pro-labor policies either because its constituents are workers or because they attach a high weight on altruistic and egalitarian goals (see Dutt and Mitra, 2005, on this point). ${ }^{5}$

A first test of a partisan ideology-based model in the context of trade policy, was carried out by Dutt and Mitra (2005). They show that left-wing (right-wing) governments tend to adopt more (less) protectionist trade policies in capital rich countries, but adopt more (less) pro-trade policies in labor rich economies. However, to the best of my knowledge, there have been no direct tests of the partisan theory on agricultural trade policy determination, although some indirect and partial evidence can be found in the work of Bates (1983). In studying the patterns of market intervention in agrarian Africa, Bates found some support for a quite counter intuitive hypothesis, namely 'that despite their stress on economic equality, socialist governments should be more likely than others to impose lower prices on the commodity from which the poorest of the poor - the peasant farmers derive their incomes' (1983: p. 299). Taken literally, Bates' result could suggest a negative link between left-wing government orientation and agricultural protection and support. A more profound test of this 'partisan hypothesis', taking care also of the potential interplay between ideology and inequality, will be given later.

\section{Data and basic specification}

To test the contrasting hypotheses summarized above on the link between protection, land inequality and ideology, use is made of data on agricultural protection and support from about 40 countries, covering all continents and different levels of development (see Appendix A.1 for the full country sample and the time period covered). The time dimension of the data spans from 1982 to 2000 , but not every country has the full coverage of the time period. The country' average time period is equal to 14 years, with a minimum of 6 years, resulting in a quite unbalanced dataset. Overall, we have from 483 to 433 observations, depending on the specification. The main limiting factor are the protection data, followed by ideology.

\section{Land inequality and ideology variables}

Our key independent variables are a measure of land inequality and of the ideological orientation of the government (left, center and right wing).

The initial Gini index (circa 1980) of the operational agricultural land holdings, landgini, is the proxy for inequality in land distribution. The information on initial land Gini come from IFAD (2001, Tab. 3.1), Keefer and Knack (1995) and FAO sources. The homogeneity of these data is a major advantage; in fact all are based on the official decennial FAO World Census of Agriculture. Moreover, while this proxy is not immune to measurement problems - referring to operational activity rather than land ownership - Deininger and Squire (1998) suggested that such data constitute a lower bound to land ownership inequality in that the rental market contributes to a more equal distribution of land

\footnotetext{
${ }^{5}$ The Partisan theory has been an important field of empirical research at the macroeconomic level, studying how the ideological orientation of governments influences unemployment, inflation and various monetary and fiscal policy instruments. (see Alesina et al., 1997).
} 
holdings. For example, in the developing countries, where data on land ownership is available, these authors find that the share of rented land was below $10 \%$ and the Gini coefficient for the distribution of operated land was lower than the Gini coefficient of owned land.

The data on the political orientation of the government are taken from the Database on Political Institution (DPI) described in Beck et al. (2001). Starting from this database and following Dutt and Mitra (2005), we constructed a cardinal measure of government ideology for each country and each year, gov_ideology, equal to 1 for right, 2 for centre and 3 for left ideology orientation. The measure is based on the ideological orientation of the chief executive for a political system classified as 'presidential' in the database, the ideological orientation of the largest government party for systems classified as 'parliamentary', and the average of these two orientations for systems classified as 'assembly-elected president'.

The gov ideology variable was used considering both its time variation and its average value over each country time period. However, the results reported below are based only on the former specification as they are totally unaffected by these different manipulations. Moreover, in the sensitivity analysis, we also experiment some manipulation aimed at taking care of the potential shortcoming in the international comparability of ideology measure.

Finally, note that for a few not democratic countries in our sample, the DPI database does not report data concerning government orientation. Thus, in regressions that include ideology as an explanatory variable, the country sample is reduced from 40 to 34 countries.

\section{Dependent variable and other controls}

The dependent variable is the aggregated producer subsidy equivalent, $p s e$, expressed as the percentage of gross farm income taken from $O E C D$ and $U S D A$ sources. It measures the percentage of farm income that comes from all government programs. The pse includes border measures, output subsidies and direct payments as well as primary and intermediate input subsidies, structural policies and the effect of indirect macroeconomic policies like an overvalued exchange rate. The advantage of using the pse is twofold: first of all, measuring the level of total income transfer from consumer/taxpayer to the agricultural sector, appears a good proxy to test political economy hypotheses; secondly, it is available for a quite large cross-section of countries.

As suggested by several previous studies (e.g., Beghin and Kherallah, 1994; Swinnen et al., 2000, 2001; Olper, 2001) a number of additional economic and political variables are likely to affect the level of agricultural protection. These additional determinants can be divided into two main broad categories: structural controls and political institution variables.

As structural controls we include, firstly, two agricultural comparative advantage proxies, landpc and expshr. The first one is based on FAO data and measures the amount of agricultural land per capita. ${ }^{6}$ The second one, expshr, measures the share of agricultural export to total export, and comes from the World Bank World Development Indicators.

\footnotetext{
${ }^{6}$ In our context the inclusion of landpc is of particular interest in order to avoid our land inequality proxy suffering systematic bias, due to the fact that more land abundant countries tend to have a consistently more unequal distribution of land.
} 
Other variables capturing structural characteristics are empshr, agshr and $g d p p c$. The first two measure the agricultural share in employment and in GDP, and are respective proxies for the relative group size and 'vast interest' in agriculture. Instead, $g d p p c$ is the log of GDP per capita to control for the so-called 'development paradox', capturing residual differences in development. All the variables were computed from FAO and World Bank sources.

Protection is also affected by political institutions that determine the decision-making framework, conditioning the ability of interest groups to shape public policies, and the agency problems between voters and politicians. Recent studies have shown that any increase in democracy affects protection positively, although not linearly (Beghin and Kherallah, 1994; Swinnen et al., 2000). Moreover, other institutional dimensions, such as the quality of institutions that protects and enforces property rights (Olper, 2001), and differences in electoral rules and forms of government (Persson and Tabellini, 2000; Henning, 2004; Olper and Raimondi, 2004) have been shown to matter a great deal in explaining policy outcomes and protection.

Here, political institutions are controlled by means of two different variables: the Gastil index of political rights (an inverse measure of democracy), compiled by Freedom House, and a composite index of quality of institution, icrg, based on data collected from the International Country Risk Guide, a private international investment risk service. The political rights proxy is a subjective index that classifies countries into 7 categories, from the best (1) to the worst (7), on the basis of several dimensions such as the existence of free and fair elections, the right to participate in the political process, and so on. On the contrary, the icrg variable is based on five different dimensions - rule of law, government repudiation, risk of expropriation, quality of bureaucracy and corruption in government - and it is included both linearly and as the square, on the ground of previous results, showing a strong inverted U-shaped relationship of this proxy with protection (see Olper, 2001). Table 1 reports summary statistics of the explanatory variables described above.

\section{Econometric methodology and results}

The econometric model is based on variations of the following general empirical equation:

Table 1

Descriptive statistics

\begin{tabular}{lrrrcrc}
\hline & Minimum & Mean & Maximum & Standard deviation & Observed & Countries \\
\hline pse & -242.7 & 20.5 & 77.2 & 40.9 & 483 & 40 \\
landgini & 21.1 & 61.3 & 97.0 & 17.7 & 489 & 40 \\
gov_ideology & 1.0 & 2.1 & 3.0 & 1.0 & 434 & 34 \\
gdppc (log) & 5.0 & 8.7 & 10.8 & 1.4 & 489 & 40 \\
empshr & 2.0. & 25.1 & 85.4 & 24.7 & 485 & 40 \\
agshr & 1.4 & 10.7 & 57.0 & 10.5 & 489 & 40 \\
expshr & 0.3 & 17.4 & 81.8 & 19.1 & 485 & 40 \\
landpc & 0.3 & 64.1 & 1091.5 & 198.9 & 489 & 40 \\
political rigths & 1.0 & 2.6 & 7.0 & 1.9 & 485 & 40 \\
icrg & 10.3 & 36.9 & 50.0 & 11.4 & 485 & 40 \\
icrgsq & 106.1 & 1486.8 & 2500.0 & 780.3 & 485 & 40 \\
\hline
\end{tabular}

Notes: See text for variables description. 


$$
\begin{aligned}
y_{i t}= & \alpha+\delta_{r}+\phi_{t}+\boldsymbol{\beta} \boldsymbol{x}_{i t}+\gamma_{0} \text { landgini }_{i}+\eta \text { gov_ideology }_{i t} \\
& +\left(\gamma_{0}-\gamma_{1}\right) \text { landgini } i_{i} *{\text { gov_ideolog } y_{i t}+u_{i t}}
\end{aligned}
$$

where $y_{i t}$ is the level of agricultural protection in country $i$ in year $t ; \alpha$ is a common intercept; $\delta_{r}$ and $\phi_{t}$ are regional-specific intercepts and time dummies, respectively; $\boldsymbol{x}_{i t}$ is the vector of structural and institutional controls described above; landgini and gov_ideology are the key variables of interest; $\beta, \eta$ and $\gamma_{i}$ denote the unknown parameters to be estimated, while $u_{i t}$ is an unobserved error term.

Using Eq. (1) let us test two main sets of hypotheses. First of all, we want to establish whether protection is influenced directly by land inequality and ideology. Finding coefficients $\gamma_{0} \neq 0$ and $\eta \neq 0$, suggests a direct, or linear, effect of land inequality and ideology on agricultural protection. Secondly, we want to know whether the effect of land inequality is conditional to the ideological orientation of the government or, differently, whether it is the effect of ideology that switches in sign under different inequality conditions. In this case, finding coefficients $\gamma_{0} \neq \gamma_{1}$ suggests that the effect of land inequality (ideology) on policy outcomes will depend on the value of government ideology (inequality). Then, studying the sign of the partial derivatives of protection with respect to inequality and ideology, respectively, we can assess endogenously from the data which kind of relationship holds.

Eq. (1) is first estimated by ordinary least squares. Then, to check the robustness of our results, we use both instrumental variable techniques and weighted least squares (WLS), to take into account the potential endogenity issues and the unbalanced structure of the panel.

\section{Regression results}

Table 2 shows the pooled regression estimates. The estimation is by ordinary least squares, and each regression always includes a set of comprehensive regional fixed effects and a set of time dummies (not shown). Regression (1) is our baseline specification, thus it omits both the land inequality and the ideology variables that, instead, are included in the successive specifications. Let us start by giving a brief account of the baseline results.

Generally speaking, the results strongly confirm, using a larger data set, the previous findings on the determinants of agricultural protection. First of all, the model as a whole is highly significant, and explains a large fraction of the cross-country and time-series variations in protection (adj $R^{2}=0.56$ ). All the control variables enter the equation with their expected signs, and are, for the most part, significant at the $1 \%$ or $5 \%$ level.

Specifically, protection increases in countries with a comparative disadvantage in agriculture. Protection is related negatively with the relative dimension of the agricultural sector, measured by the employment share, but the relation is positive and significant when the economic size of agriculture is measured as the share of GDP. Moreover, protection increases weakly with democracy, but shows a strong inverse U-shaped pattern with the subjective index of the extent of maintenance institution quality. Finally, in terms of regional fixed effects we find that, conditional to previous explanatory variables, agricultural protection is lower in African countries and higher in Asian and European countries.

Regression (2) adds to our 'benchmark' the first key variable of interest, inequality in agricultural land measured as the Gini index. The land Gini enters the equation with a negative and highly significant coefficient ( $p$-value $>0.01)$, showing that protection decreases in countries with high inequality in land distribution. These results cast some doubt on the findings of Van Bastelaer (1998), who shows a positive association between 
Table 2

Land inequality, ideology and protection: regression results

\begin{tabular}{|c|c|c|c|c|c|c|c|c|}
\hline \multirow[t]{3}{*}{ Variables } & \multicolumn{8}{|c|}{ Dependent variable PSE $\%$} \\
\hline & \multicolumn{2}{|l|}{ Eq. (1) } & \multicolumn{2}{|l|}{ Eq. (2) } & \multicolumn{2}{|l|}{ Eq. (3) } & \multicolumn{2}{|l|}{ Eq. (4) } \\
\hline & Coefficient & $t$-values & Coefficient & $t$-values & Coefficient & $t$-values & Coefficient & $t$-values \\
\hline$g d p p c$ & 19.96 & 4.69 & 18.68 & 4.44 & 22.68 & 5.08 & 22.91 & 5.31 \\
\hline empshr & -0.32 & -1.89 & -0.36 & -2.14 & -0.56 & -2.89 & -0.42 & -2.19 \\
\hline agshr & 2.31 & 6.85 & 2.17 & 6.47 & 3.04 & 7.92 & 3.01 & 8.11 \\
\hline expshr & -0.56 & -5.12 & -0.37 & -3.11 & -0.59 & -4.61 & -0.53 & -4.31 \\
\hline landpc & -0.02 & -2.40 & -0.01 & -1.31 & -0.01 & -1.28 & -0.01 & -1.34 \\
\hline political rights & -1.23 & -1.14 & -1.84 & -1.71 & -3.68 & -3.37 & -3.62 & -3.43 \\
\hline icrg & 4.77 & 4.34 & 4.48 & 4.13 & 5.29 & 4.39 & 5.48 & 4.71 \\
\hline icrgsq & -0.06 & -3.58 & -0.06 & -3.39 & -0.08 & -4.17 & -0.08 & -4.38 \\
\hline landgini & & & -0.43 & -3.65 & -0.78 & -6.14 & -1.83 & -8.01 \\
\hline gov_ideology & & & & & -4.62 & -3.01 & -31.81 & -6.11 \\
\hline $\begin{array}{l}\text { landgini* } \\
\text { gov_ideology }\end{array}$ & & & & & & & 0.43 & 5.45 \\
\hline \multicolumn{9}{|c|}{ Regional dummies } \\
\hline d_lam & 4.35 & 0.61 & 6.60 & 0.93 & -13.02 & -2.08 & 17.90 & 2.62 \\
\hline d_asia & 11.72 & 2.00 & 4.49 & 0.74 & 3.93 & 0.57 & -17.34 & -2.82 \\
\hline$d \_a f r$ & -12.59 & -1.93 & -11.94 & -1.86 & -6.38 & -0.88 & 0.21 & 0.03 \\
\hline d_nam & 1.10 & 0.20 & 1.98 & 0.37 & 7.08 & 1.08 & 8.66 & 1.67 \\
\hline d_ceec & 13.24 & 1.77 & 17.06 & 2.29 & -0.53 & -0.10 & 29.47 & 3.87 \\
\hline d_eur & 13.59 & 2.04 & 11.62 & 1.76 & 6.21 & 0.92 & 11.37 & 1.80 \\
\hline d_pacific & 3.73 & 0.40 & 2.49 & 0.27 & 20.36 & 2.05 & 22.38 & 2.54 \\
\hline \# Obs & \multicolumn{2}{|c|}{483} & \multicolumn{2}{|c|}{483} & \multicolumn{2}{|c|}{433} & \multicolumn{2}{|c|}{433} \\
\hline $\operatorname{Adj} R 2$ & \multicolumn{2}{|c|}{0.56} & \multicolumn{2}{|c|}{0.57} & \multicolumn{2}{|c|}{0.59} & \multicolumn{2}{|c|}{0.62} \\
\hline$F$-statistic & \multicolumn{2}{|c|}{19.41} & \multicolumn{2}{|c|}{19.76} & \multicolumn{2}{|c|}{18.75} & \multicolumn{2}{|c|}{20.37} \\
\hline
\end{tabular}

Notes: OLS regressions. All equations include also a set of year dummies (see text).

a proxy of land inequality and agricultural protection, in line with the Olsonian logic discussed above. ${ }^{7}$ On the contrary, the results support the view that inequality in assets ownership among group members may cause collective action problems of various types, as suggested by, among others, Bardhan et al. (2001) and La Ferrara (2002).

The inclusion of land Gini does not substantially affect other regression coefficients. The main changes with respect to our 'benchmark' are related to the comparative advantage proxies. Now the land per capita variable loses its significance, ${ }^{8}$ while the (absolute) value of agricultural export share coefficient is lower but still highly significant.

Next, regression (3) adds the ideology of government as an explanatory variable to the previous specification. As can be seen, the gov_ideology coefficient is negative and highly significant $(p$-value $>0.01)$. Because our ideology proxy increases with a left orientation, a

\footnotetext{
${ }^{7}$ Olper (2003) has shown that the positive link between land inequality and agricultural protection obtained in Van Bastelaer (1998) is a combination of two main shortcomings: the poor land inequality proxy used there (holdings per agricultural worker) and the failure to control for political institutions.

${ }^{8}$ The fact that our land inequality proxy is strongly significant, also in the presence of the agricultural land per person active in agriculture, suggests that landgini does not suffer from systematic bias, due to the fact that more abundant countries tend to have a consistently more unequal land distribution.
} 
negative coefficient on this variable means that protection increases on passing from the left to the right of the political spectrum. Thus, the data show that, in agriculture, right-wing governments are more protectionist than left-wing governments. These results confirm and extend the findings of Bates (1983) on the patterns of market intervention in agrarian Africa, where he showed that ideology matters in setting food price policy.

The inclusion of the government ideology proxy affects the coefficients of some key explanatory variables. Specifically, comparing the results of regression (2) with regression (3), it can be seen that the coefficients of land Gini and political rights (our inverse index of democracy) increase in their absolute magnitude, and are now estimated with more precision.

The last columns of Table 2 directly test the possibility that the response of redistributive trade policy to land inequality and ideology is conditional to the interaction between these two variables. For example, one can suppose that if politicians are partisan, then in an unequal society a left-wing government could have a strong rationale for redistribution, potentially affecting the ideology-protection relationship. To this end, regression (4) includes in the specification also the interaction between land Gini and government ideology (landgini*gov_ideology), removing the restriction from Eq. (1) that $\gamma_{0}=\gamma_{1} \cdot{ }^{9}$

The results are quite interesting. First, the interaction term is positive and strongly significant. At the same time the (absolute) linear coefficients of both the land Gini and the ideology variables increase substantially in magnitude and significance. To better understand these relationships, we have used the results of regression (4) to study the sign of the partial derivatives of protection with respect to inequality and ideology. In the first case we have, apse/dlandgini $=-1.83+0.43^{*}$ gov_ideology, which is negative at all levels of the ideology values (gov_ideology $\leqslant 3$ ). Differently, in the second case we have, apse/ agovideology $=-31.81+0.43 *$ landgini, which is negative (positive) for landgini values below (above) $74(=31.81 / 0.43)$ Gini points, that represent the land inequality turning point. Note that, while this number is somewhat higher than the median (60.2) and the mean (61.6) of the land Gini distribution, it lies largely within its range.

Summing up, the data show that land inequality affects protection negatively, although this negative effect appears mitigated on passing from right-wing to left-wing government orientation. Instead, left-wing government orientation - that, on average, tends to tax agriculture - in a more unequal society tends to protect it. Interestingly, very similar results were obtained by Lee and Roemer (2002) in studying the relationship between income inequality and redistribution at the aggregate level.

Finally, it could be interesting to check whether our relationship holds up better in democracy than in dictatorship, or vice-versa. Indeed, one can think that the government response to lobbying may be stronger in democracy than in dictatorship. To see this, we borrow the simple method used by Dutt and Mitra (2002), and regress the absolute residual of regression (4) on our inverse index of democracy, plus a constant. The results are as follows ( $t$-value are shown in parentheses, under the coefficients):

\footnotetext{
${ }^{9}$ We have also tried interaction terms between land inequality with democracy and/or GDP per-capita, on the grounds that democracies (or more developed countries) might be more responsive to demand for redistribution. In some specifications these interactions turn out to be significant. However, their significance always disappears when the (preferred) landgini*govideology interaction is included in the specification.
} 


$$
\mid \text { pse residual } \mid=\underset{(6.95)}{8.83^{* * *}}+\underset{(6.77)}{2.98^{* * *}}(\text { political rights }) R^{2}=0.10
$$

Because the political rights variable increases in the extent of dictatorship, its positive coefficient means that larger absolute residuals are positively correlated with less democracy. Thus, there is some evidence that our model works better in democracies than in dictatorships. ${ }^{10}$

\section{Robustness checks}

In this section we briefly take into account the main potential econometric problems of the results presented above. A first problem can be derived from endogeneity issues in some of the explanatory variables, leading to simultaneity bias. In general terms, our key variables of interest - landgini and gov_ideology - are not affected, for different and quite intuitive reasons, by changes in agricultural protection. However, it can be argued that in countries with high levels of asset inequality left-wing governments have higher chances of being elected. If this is the case, then political ideology is endogenous with respect to the level of land inequality. However this argument is not supported by the data. Indeed the correlation between left-wing government and land inequality is close to zero $(-0.08){ }^{11}$

Next, as discussed in Beghin and Kherallah (1994) and Swinnen et al. (2001), causality problems can exist for other explanatory variables such as empshr, agshr and expshr that could, themselves, be affected by agricultural protection. Thus, following previous studies, we performed a Granger causality test for the above three variables with respect to the independent pse variable. The tests reject the causality hypothesis for agshr and expshr but not for empshr. Therefore, we performed a two stage least squares estimation, where we employed fertility rate and pse lagged one year as instruments for empshr. Moreover, because the Granger causality test is not robust against monotonic transformation (see Swinnen et al., 2001), we also use as instruments for agshr and expshr, their (2 years) lagged values. The results are reported in regression (1) of Table 3. As can be seen, the parameter estimates suggest that our results and conclusions are not affected to any degree by endogenity issues.

Another possible econometric problem could derive from the unbalanced nature of our data set. Specifically, the length of each country panel is systematically larger for developed countries than for developing countries (see Appendix A.1). Thus, our previous OLS results are driven more by observations of developed countries, and this can be a problem because our key variable of interest, landgini, displays only cross-country variation.

To take into account this potential econometric issue, use was made of weighted least squares estimation method, where each country's weight is proportional to the length of its panel. The results of the WLS regression are shown in regression (2) of Table 3, and they are essentially unchanged with respect to OLS regression. Indeed, the coefficient of land-

\footnotetext{
${ }^{10}$ We have also run regressions with additional interaction terms between ideology and democracy and between ideology, land Gini and democracy. However both interaction terms turn out to be insignificant.

11 As a further check we regress ideology on land Gini, and then the residuals of this regression are used as a proxy for ideology in the model. By doing so, the results are totally unaffected.
} 
Table 3

Land inequality, ideology and protection: robustness checks

\begin{tabular}{|c|c|c|c|c|c|c|}
\hline \multirow[t]{3}{*}{ Variables } & \multicolumn{6}{|c|}{ Dependent variable PSE ( $\%)$} \\
\hline & \multicolumn{2}{|l|}{ Eq. (1) } & \multicolumn{2}{|l|}{ Eq. (2) } & \multicolumn{2}{|l|}{ Eq. (3) } \\
\hline & Coefficient & $t$-values & Coefficient & $t$-values & Coefficient & $t$-values \\
\hline$g d p p c$ & 20.63 & 3.33 & 29.48 & 5.23 & 22.85 & 5.79 \\
\hline empshr & -0.67 & -1.68 & -0.40 & -1.82 & -0.16 & -0.88 \\
\hline agshr & 3.63 & 8.56 & 3.44 & 9.22 & 3.07 & 8.96 \\
\hline expshr & -0.50 & -3.63 & -0.61 & -4.85 & -0.56 & -4.84 \\
\hline landpc & -0.01 & -1.46 & -0.02 & -1.14 & -0.02 & -1.73 \\
\hline political rights & -4.02 & -3.57 & -7.97 & -6.34 & -2.52 & -2.57 \\
\hline$i c r g$ & 6.16 & 5.25 & 6.02 & 4.49 & 6.22 & 5.74 \\
\hline$i c r g s q$ & -0.08 & -4.62 & -0.10 & -4.26 & -0.08 & -5.05 \\
\hline landgini & -1.97 & -8.81 & -2.52 & -7.90 & -2.60 & -12.52 \\
\hline gov_ideology & -33.40 & -6.22 & -47.01 & -6.65 & -37.79 & -11.00 \\
\hline landgini * gov_ideology & 0.46 & 5.71 & 0.65 & 6.28 & 0.54 & 10.21 \\
\hline Regional dummies & \multicolumn{2}{|c|}{ Yes } & \multicolumn{2}{|c|}{ Yes } & \multicolumn{2}{|c|}{ Yes } \\
\hline \# Observed & \multicolumn{2}{|c|}{400} & \multicolumn{2}{|c|}{433} & \multicolumn{2}{|c|}{433} \\
\hline $\operatorname{Adj} R 2$ & \multicolumn{2}{|c|}{0.64} & \multicolumn{2}{|c|}{0.53} & \multicolumn{2}{|c|}{0.68} \\
\hline$F$-statistic & \multicolumn{2}{|c|}{21.18} & \multicolumn{2}{|c|}{15.96} & \multicolumn{2}{|c|}{26.12} \\
\hline
\end{tabular}

Notes: Eq. (1) is estimated via 2SLS, using as instruments the fertility rate and the pse lagged one year for empshr, and agshr and expshr lagged two years instead of their contemporaneous values. Eq. (2) is estimated via WLS, with weights proportional to the length of each country panel. Eq. (3) is a simple OLS regression, where the gov_ideology variable has been adjusted to take into account its international comparability (see text). All equations include a set of year dummies.

gini and gov_ideology (and their interaction) are even greater in absolute magnitude and significance.

A final potential weakness of our results could be due to the international comparability of the ideology measure (see Dutt and Mitra, 2005). In fact, it can be argued that a leftwing party in one country could be regarded as centrist or right-wing in another country. For example, the 'ideology' of a leftist North American party is probably quite different from the 'ideology' of a leftist European party. In general terms, the regressions presented above could be quite robust to this problem as they always include a very comprehensive set of regional fixed-effect dummies. In fact, it is quite plausible that countries from the same region have more similar notions of left/right ideology.

However, to be on the safe side, we further checked the robustness of the results by adjusting country- and region-specific variation in the ideology definition, as suggested by Dutt and Mitra (2005). These adjustments are based on a larger magnitude of the left/right scale, now spanning from 1 (most right oriented) to 5 (most left oriented). ${ }^{12}$

As can be seen from the last regression of Table 3, the results are very robust to this manipulation. In fact, the ideology and land inequality coefficients (and their interaction) are now estimated with more precision (higher $t$-values), the explanatory power of the

\footnotetext{
${ }^{12}$ The main adjustments are as follows: For the US the ideology scale remains the same $(1=$ Republicans, $3=$ Democrats); for Latin America right $=1$, centre $=3$ and left $=5$; for China left $=5$; for Europe, UK and Ireland retained the original coding, while the others recoded as right $=2$, centre $=3$ and left $=4$.
} 
model is significantly higher (the adj $R^{2}$ increases from 0.62 to 0.68 ), and the estimated land inequality turning point is now lower $(69.9=37.79 / 0.54)$, thus much closer to the mean and the median of the landgini distribution.

\section{Discussion and conclusions}

In this paper it is investigated empirically how inequality in land distribution affects the patterns of agricultural protection, taking into consideration the role played by the ideological orientation of the government. Theoretically, these links are quite ambiguous, switching from positive to negative depending on the underlying political economic structure. For instance, models based on the median voter approach suggest a positive link between assets inequality and government redistribution regardless of who governs, while the prediction of lobby models suggests both negative and positive or even non-monotonic relationships.

The data and results show that agricultural protection decreases with both land inequality and left-wing government orientation, but not in a linear fashion. Indeed leftwing governments - that, on average, tax agriculture - tend to protect it in more unequal society. The underlying reason could be that in countries with strong unequal land distribution the demand for redistribution of the median voter tends to overlap the partisan interest of the government, if a left-wing government is in office. Thus, while our empirical evidence is inconsistent with a pure median-voter approach, it also appears that elements of general-interest politics are at work in driving the results.

Overall, the data support the more recent literature on assets inequality and collective action, where inequality among members of a group can produce different types of collective action problems, reducing co-operation and the provision of public goods. At the same time, however, the results strongly support the idea that policy determination is also driven by the partisan nature of the government: ideology orientation matters in explaining the level of protection, affecting also the interplay between inequality and protection. Finally, there is evidence that the overall model holds up better in democracies than in dictatorships.

Summing up, the empirical findings reinforce the idea that it is the public and private institutions that, through their action on the incentive structure, provide the critical elements in the policy-making process. The formulation and implementation of sound economic policies can only be achieved through a better understanding of the interplay between policy variables and institutions. From this perspective, this paper has highlighted the important role played by land inequality and political ideology on agricultural protection.

\section{Acknowledgements}

The author thanks Dario Casati and Francesco Lechi for their helpful comments on an early draft. Moreover, I wish to thank the editor and two anonymous referees, for their suggestions. The research was carried out as part of the 2003 FIRST (Fondo interno di ricerca scientifica e tecnologica) project, Università degli Studi di Milano: 'Accordi commerciali multilaterali e riforma della politica agricola comune tra vecchie e nuove forme di protezionismo'. 
Appendix A. See Table A.1.

Table A.1

Countries and time period covered

\begin{tabular}{|c|c|c|c|c|c|}
\hline 1 & Argentina & 1982-1992 & 21 & Mexico & $1982-2000$ \\
\hline 2 & Australia & $1982-2000$ & 22 & New Zealand & $1982-2000$ \\
\hline 3 & Austria & 1982-1994 & 23 & Nigeria $^{a}$ & 1982-1989 \\
\hline 4 & Bangladesh $^{\mathrm{a}}$ & $1982-1987$ & 24 & Norway & $1982-2000$ \\
\hline 5 & Brazil & $1982-1987$ & 25 & Pakistan & 1982-1987 \\
\hline 6 & Canada & $1982-2000$ & 26 & Poland & $1986-2000$ \\
\hline 7 & Chile & 1987-1992 & 27 & Senegal & 1982-1989 \\
\hline 8 & China & 1984-1992 & 28 & Slovakia & 1986-2000 \\
\hline 9 & Colombia & 1982-1992 & 29 & Slovenia & $1986-2000$ \\
\hline 10 & Czech Republic & 1986-2000 & 30 & South Africa & 1982-1989 \\
\hline 11 & Egypt $^{\mathrm{a}}$ & 1982-1992 & 31 & Sweden & 1982-1994 \\
\hline 12 & European Union & $1982-2000$ & 32 & Switzerland & $1982-2000$ \\
\hline 13 & Finland & 1982-1994 & 33 & Taiwan & 1982-1987 \\
\hline 14 & Hungary & $1986-2000$ & 34 & Tanzania & 1982-1989 \\
\hline 15 & India & 1982-1990 & 35 & Thailand & 1982-1987 \\
\hline 16 & Indonesia $^{a}$ & $1982-1987$ & 36 & Turkey & $1982-2000$ \\
\hline 17 & Jamaica & 1982-1989 & 37 & USA & $1982-2000$ \\
\hline 18 & Japan & 1982-1992 & 38 & Venezuela & 1982-1987 \\
\hline 19 & Kenya $^{a}$ & 1982-1989 & 39 & Zambia & 1982-1991 \\
\hline 20 & Korea & $1982-2000$ & 40 & Zimbabwe $^{\mathrm{a}}$ & 1982-1989 \\
\hline
\end{tabular}

${ }^{\text {a }}$ Countries, where gov_ideology variable is not classifiable.

\section{References}

Alesina, A., Rodrik, D., 1994. Distributive politics and economic growth. Quarterly Journal of Economics 108, 456-490.

Alesina, A., Roubini, N., Cohen, G.D., 1997. Political Cycles and the Macroeconomy. The MIT Press, Cambridge, MA.

Baland, J.-M., Platteau, J.-P., 1997. Wealth inequality and efficiency in the commons, part i: the unregulated case. Oxford Economic Papers 49, 451-482.

Bardhan, P., 2000. Irrigation and cooperation: an empirical analyses of 48 irrigation communities in South India. Economic Development and Cultural Change 48, 847-865.

Bardhan, P., Dayton-Johnson, J., 2002. Inequality and the Governance of Water resource in Mexico and South India. Working Paper, University of California at Berkeley, February, 2002.

Bardhan, P., Ghatak, M. Karaivanov, A., 2001. Inequality and Collective Action. Working Paper, University of California at Berkeley, August, 2001.

Barrett, C.B., 1999. The microeconomics of the developmental paradox: on the political economy of food price policy. Agricultural Economics 20 (2), 159-172.

Bates, R.H., 1983. Patterns of market intervention in agrarian Africa. Food Policy 8 (4), 297-312.

Beck, T., Clarke, G., Groff, A., Keefer, P., 2001. New tools in comparative political economy: the database of political institutions. World Bank Economic Review 15, 165-176.

Beghin, J.C., Kherallah, M., 1994. Political institutions and international patterns of agricultural protection. Review of Economics and Statistic LXXVI, 482-489.

Bergstrom, M., Blume, L., Varian, H., 1986. On the private provision of public goods. Journal of Public Economics 29, 25-49.

Binswanger, H.P., Deininger, K., 1997. Explaining agricultural and agrarian policies in developing countries. Journal of Economics Literature XXXV (4), 1958-2005.

De Gorter, H., Swinnen, J., 2002. Political economy of agricultural policy. In: Gardner, B., Rausser, G. (Eds.), Handbook of Agricultural Economics, vol. 2B, pp. 1893-1943. 
De Janvry, A., Sadoulet, E., Fafchamps, M., 1989. Agrarian structure, technological innovation, and the state. In: Bardhan, P. (Ed.), The Economics Theory of Agrarian Institution. Clarendon Press, Oxford.

Deininger, K., Olinto, P., 2000. Asset Distribution, Inequality, and Growth. Policy Research Working Paper No. 2375. World Bank.

Deininger, K., Squire, L., 1998. New ways of looking at old issues: inequality and growth. Journal of Development Economics 57 (2), 259-287.

Dutt, P., Mitra, D., 2002. Endogenous trade policy through majority voting: an empirical investigation. Journal of International Economics 58, 107-133.

Dutt, P., Mitra, D., 2003. Labour versus Capital in Trade-Policy determination: the Role of General-Interest and Special-Interest Politics. Working Paper No. 10084, National Bureau of Economic Research, November, 2003.

Dutt, P., Mitra, D., 2005. Political ideology and endogenous trade policy: an empirical investigation. Review of Economic and Statistic 87 (1), 59-72.

Easter, K., Palanisami, K., 1986. Tank Irrigation in India and Thailand: An Example of Common Property Resource Management. Department of Agricultural and Applied Economics, Staff Paper, University of Minnesota.

Gawande, K., Bandyopadhyay, U., 2000. Is protection for sale? A test of the Grossman-Helpman theory of endogenous protection. Review of Economics and Statistics 82 (1), 139-152.

Goldberg, P., Maggi, G., 1999. Protection for sale: an empirical investigation. American Economic Review 89 (5), 1135-1155.

Grossman, G., Helpman, E., 1994. Protection for sale. American Economic Review 84 (4), 833-850.

Henning, C.H.C.A., 2004. The role of institutions in agricultural protectionism. In: Van Huylenbroeck, G., Verbeke, W., Lauwers, L. (Eds.), Role of Institutions in Rural Policies and Agricultural Markets. Elsevier, Amsterdam, pp. 137-151.

Hiscox, M.J., 2002. Will trade be a partisan issue again (and why isn't it already?). Trade and the American Political Parties in the 1980s and 1990s. Paper presented at the Conference on the The Political Economy of Globalisation. Can the Past Inform the Present? Trinity College, Dublin, August 29-31, 2002.

International Fund for Agricultural Development (IFAD), 2001. Rural Poverty Report 2001. Oxford University Press, New York.

Kau, J., Rubin, P.H., 1979. Self interest, ideology and logrolling in congressional voting. Journal of Low and Economics 22 (2), 365-384.

Keefer, P., Knack, S., 1995. Polarization, Property Rights and the Links between Inequality and Growth. IRIS Working Paper No. 153,University of Maryland at College Park, April 1995.

Krueger, A.O., Shiff, M., Valdés, A. (Eds.), 1991. Political Economy of Agricultural Pricing Policy. Johns Hopkins University Press, Baltimore.

La Ferrara, E., 2002. Inequality and group participation: theory and evidence from rural Tanzania. Journal of Public Economics 85 (2), 235-273.

Lee, W., Roemer, J.E., 2002. The rise and fall of unionised labour markets: a political economy approach. The Economic Journal 115, 28-67.

Magee, C., 2002. Endogenous trade policy and lobby formation: an application to the free-rider problem. Journal of International Economics 57 (2), 449-471.

Mayer, W., 1984. Endogenous tariff formation. American Economic Review 74 (5), 970-985.

Mitra, D., 1999. Endogenous lobby formation and endogenous protection: a long run model of trade policy determination. American Economic Review 89 (5), 1116-1134.

Olper, A., 2001. Determinants of agricultural protection: the role of democracy and institutional setting. Journal of Agricultural Economics 52 (2), 75-92.

Olper, A., 2003. Land inequality, collective action and agricultural protection: a note. Poster paper presented at the 25th International Conference of Agricultural Economists "Reshaping Agriculture's Contribution to Society". Durban, South Africa,16-22 August 2003.

Olper, A., Raimondi, V., 2004. Political institutions and milk policy outcomes in OECD countries. In: Van Huylenbroeck, G., Verbeke, W., Lauwers, L. (Eds.), Role of Institutions in Rural Policies and Agricultural Markets. Elsevier, Amsterdam, pp. 153-168.

Olson, M., 1965. The Logic of Collective Action. Public Goods and the Theory of Groups. Harvard University Press, Cambridge.

Pecorino, P., 1998. Is there a free-rider problem in lobbying? Endogenous tariffs, trigger strategies, and the number of firms. American Economic Review 88 (3), 652-660. 
Peltzman, S., 1984. Constituent interest and congressional voting. Journal of Law and Economics 27 (2), 181-210. Persson, T., Tabellini, G., 2000. Political Economics: Explaining Economic Policy. MIT Press, Cambridge, MA. August 2000.

Stiglitz, J., 1998. Distribution, efficiency and voice: designing the second generation of reforms. Paper presented at the Conference on Asset Distribution, Poverty, and Economic Growth. Brasilia, Brazil, July 14, 1998.

Swinnen, J.F.M., 2002. Political reforms, rural crises, and land tenure in western Europe. Food Policy 27, 371394.

Swinnen, J.F., de Gorter, H., Rausser, G.C., Banerjee, A.N., 2000. The political economy of public research investment and commodity policy in agriculture: An empirical study. Agricultural Economics 22 (2), 111-122.

Swinnen, J.F., Banerjee, A.N., de Gorter, H., 2001. Economic development, institutional economy of agricultural protection. An econometric study of Belgium since the 19th century. Agricultural Economics 26 (1), 25-43.

Timmer, C.P., 2002. Agriculture and economic development. In: Gardner, B., Rausser, G. (Eds.), Handbook of Agricultural Economics, vol. 2A, pp. 1487-1546.

Van Bastelaer, T., 1998. The political economy of food pricing: an extended empirical test of the interest group approach. Public Choice 96, 43-60. 